\title{
Public Perception of the Quality of Academic Education Program
}

\author{
Binod Krishna Shrestha* \\ School of Management, Kathmandu University, Lalitpur, Nepal
}

\begin{abstract}
There is no information on what exactly quality is as perceived by the public as the potential recipients of education programs to guide policy makers to deliver quality. This study explored the determinants of quality of education program as perceived by the public. This study is important because a quality concept starts from customers according to which the providers should develop their programs. Following the theory of customers' perceptions, this study assessed stakeholders' beliefs about quality of education program rather than objective reality that organizations offer as quality education. Through a survey on about 220 respondents and corresponding data analysis, this study found out the determinants of perceived quality of education with special reference to MBA programs in Nepal. The variables included in this study were quality of faculty, quality of infrastructure, graduate employability, curriculum and reputation as antecedents of perceived quality and perceived value. This study found out that perceived quality is determined by reputation of the program as credible and trustworthy which is influenced by graduate employability, practical curriculum and competent faculty.
\end{abstract}

Keywords: perceived quality, perceived value, market reputation, total quality management, customers of higher education

There is confusion about what constitutes quality of education for those who are direct or indirect recipients of higher education such as public in general which include students, parents, faculty and employers. Although, quality of education is generally explained from the perspective of total quality management (TQM), its applications have several limitations. TQM approach focuses on organizational process in line with maximizing satisfaction of its customers as students but education has multiple stakeholders with varying expectations (Srikanthan \& Dalrymple, 2003). In addition, focusing on satisfying students' expectations alone is not comprehensive enough because the students are parts of input, process and output (IPO) of the education system (Owlia \& Aspinwall, 1996). The public include parents, faculty members, students, employers and general society, and each of them has different expectations. For example, parents may be interested in inputs such as faculty, infrastructure and reputation; and employers may be interested in graduates' readiness to employment. 
Education institutions try hard to draw attention of the public so that they can attract and enroll as many students as possible. There is a plethora of advertisements and other types of marketing promotions during admission period to depict quality of education program offered by different organizations. Likewise, there are different types of performance rankings of higher education which are mainly focused on student customers (Dill \& Soo, 2005). Development of quality perception is required for drawing attention, delivery of program and satisfying customers' needs according to marketing perspective. Quality perception is subjective judgment of customers rather than objective reality (Schiffman, Kanuk, \& Kumar, 2010). Several researches have indicated the antecedents of quality perceptions in customers as students but stakeholders' perception of quality of education programs has not been empirically measured so far.

As a result, neither quality of education programs in offer can be ascertained nor can the associated promotion program be designed as per expected quality needs and wants of the public. Similarly, parents and other stakeholders who advise and sponsor students for the study do not have precise idea about what to look for in the education and promotion programs. In short, there is no information on what exactly quality is as perceived by the public. Therefore, this study explored the determinants of quality as perceived by the public.

The theory of consumer perception states that individuals select, organize and interpret expected physical (intrinsic) and symbolic (extrinsic) attributes to draw their meaning and picture of quality of any particular objects (Schiffman, Kanuk, \& Kumar, 2010). In this line, this study used two constructs for measuring the perceived quality. One was perceived quality in terms of public's subjective judgments of functional attributes and benefits and their consistency and reliability of education program (Kotler \& Keller, 2009), and the other was perceived value which is public's subjective judgment of functional attributes and benefits as against the price and costs of the program (Netemeyer et al., 2004). With reference to different literature on choice factors for students of higher education, five quality indicators belonging to inputs, process and outputs were used as determinants of quality perceptions. They were reputation, physical facilities, quality of teachers, curriculum and employment opportunities for students (Bindsardi \& Ekwulugo, 2003; Gatfield, Braker, \& Graham, 1999; Ho \& Hung, 2008). Therefore, this study empirically examined the influence of these quality indicators on perceived quality and perceived value; and relationship among the variables.

\section{Literature Review}

Literature generally discusses total quality management for education and corresponding monitoring and evaluation of quality. However, applications of total quality management (TQM) do not match with educational processes and quality expectations of the stakeholders (Srikanthan \& Dalrymple, 2003). In addition, TQM perspective is relevant to organizational process, but not to the perspective of different types of customers and users (Sahney, Banwet, \& Karunes, 2004). In addition, TQM perspective of satisfying student customers is problematic as the students are the parts 
of input, process and output (IPO) of education system. In a system approach, input refers to the students' capacity to fulfill entry requirement; process includes students as a vital part of teaching and learning process involving the course and its delivery mechanism, professors' knowledge, and assessment method; and output includes students' readiness for placement, academic performance and financially rewarding job (Owlia \& Aspinwall, 1996).

Different types of customers perceive quality differently. Parents perceive quality that is related to reputation of education institutes and graduate employability. Students focus on education process and output. Faculty members perceive quality as relating to whole education system involving input-process-output. Finally, employers perceive quality from the perspective of the output such as skills that the students bring to the workplace (Chua, 2004).

In order to address the ambiguities in understanding public perception of quality of education, this study used marketing perspective. Perceived quality is an expression of functionality of education and its delivery system of a particular institution's offer as perceived by associated stakeholders. Functional performance is commonly understood as perceived quality. Perceived quality is defined as the customers' subjective evaluation of the product (Zeithamal, 1988). Research in marketing of quality higher education is a recent initiative and has focused mainly on students as customers. For example, global marketing of higher education services has forced providers of higher education to pay greater attentions to what students value (Ivy, 2001; Vaira, 2004). Research indicates that students are increasingly becoming critical and analytical when they choose a university (Bindsardi \& Ekwulugo, 2003). Higher education institutions are involved in increasingly intense struggles to attract new students by claiming that they offer quality education (Nicholls, Harris, Morgan, Clarke, \& Sims, 1995; Soutar \& Turner, 2002).

Nevertheless assessing the quality of higher education is a complex decision (Baldwin \& James, 2000). Gatfield, Braker, and Graham (1999) found that reputation, quality of teachers and resources, and campus lives are important quality factors for students. Similarly, Bindsardi and Ekwulugo (2003) found that the students' choice of institutions was affected by education standard of that institution and its credibility and employment opportunities. The rank and accreditation as reputation is also used by the most attractive segments of students mainly from high income families (Dill, 2003). Ho and Hung (2008) found that the five most important factors in students' school selection were employability, curriculum, academic reputation, faculty, and research environment.

The reputation of the country in which the educational institution is located is important to students (Srikantanyoo \& Gnoth, 2002), and the programs offered in developed countries are perceived to be of high quality (Bourkie, 2002). In line with this, Gray, Fam, and Llanes (2003) found that international alliances and off shore teaching programs were the predictors of market success. Likewise, Bourkie (2002) found that the most critical variables affecting student choice decision were information about the institution, its programs, facilities and services. 
Although the previous researches indicated the quality dimensions to derive choice factors for the students, there is no such study on the public, who advise and sponsor students to apply and think about the quality. Need for a research was realized to address the limitation in the existing literature on public perception of quality higher education program. This study empirically examined different aspects as determinants of perceived quality for the stakeholders.

Using the theory of customers' perception, this study used the construct of perceived quality as the public's subjective judgments of functional attributes and benefits and their consistency and reliability of educational program (Kotler \& Keller, 2009). This definition is similar to an approach of defining quality in terms of consistency and conformity of education standards in line with customers' satisfaction with the attributes (Sahney, Banwet, \& Karunes, 2004). Consistent with the approach of quality of value for money through efficiency and effectiveness, perceived value was used as another construct of quality. The perceived value refers to overall assessments of attributes and benefits of education program against price and costs of the program (Netemeyer et al., 2004). The first definition is general quality perception in relation to benefits from the attributes and the second definition is attributes in relation to costs. Different five quality indicators belonging to inputs, process and outputs such as infrastructure, reputation, curriculum, faculty, and employability were used as independent variables. Based on the literature review, these attributes were used as independent variables for both the dependent variables - perceived quality and perceived value.

\section{Method}

This study was carried out in the context of MBA program which is one of the emerging education programs offered by different institutions with attractive advertisement and promotions. A survey was carried out on the people who were familiar with different MBA programs offered by different institutions in Nepal. The respondents had also advised MBA applicants and students to select a particular higher education institution against competing institutions. These conditions of the respondents ensured that they are able to give their authentic opinion after getting exposures to different aspects of MBA programs of their most familiar business schools and their MBA programs.

\section{Instrument}

An instrument developed for measuring different attributes of brand equity of education program (Shrestha, 2011) was used for this study. This instrument contains eighteen statements for measuring five quality indicators. Three statements were used for measuring the quality of curriculum, three statements for quality of faculty, four statements for graduate employability, five statements for quality of infrastructure and three statements for reputation. This instrument was reported to have sufficient reliability and validity indicators. In addition, the instrument with four items for perceived quality and three items for perceived value (Pappu, Quester, \& Cooksey, 2005) was used in order to measure the outcome variables. Questions on biographic 
data were also added in the questionnaire. The respondents were requested to read the statements carefully and to give their opinions honestly. They were told that there were no right and wrong answers. All the variables were measured through five point Likert scale anchoring 1 for strongly disagree and 5 for strongly agree.

\section{Sample}

Three hundred questionnaires were given to MBA students who were asked to contact the respondents who had advised them during application to their MBA programs. Altogether 221 usable questionnaires were returned for the data analysis.

Among the respondents $52.5 \%$ were male. About $73.3 \%$ of the respondents were between 21 to 30 years of age. A majority of them (56.6\%) had bachelor degree and the other $28.5 \%$ had masters' degree. About $21 \%$ had been running private business organizations as their occupations and $39.4 \%$ were the students studying in different institutions. Among the respondents, 50.5\% were relatives. Friends and teachers accounted for $40 \%$ and $9.5 \%$ respectively.

\section{Data Processing}

After the collection of the data, they were processed for measuring construct reliability through factor analysis and Cronbach's alphas. In the beginning there were eighteen statements belonging to the antecedent variables namely curriculum, faculty, infrastructure, employability and reputation. All those statements were included in a factor analysis to see whether the items were loaded in the respective factors. The analysis showed that the statements measured the intended constructs because desired factors were extracted by factor analysis except in one factor in which the statements measuring faculty and curriculum were loaded together. This was because all the statements measuring faculty and curriculum were highly correlated. In addition, only two statements measuring quality of curriculum were loaded together with quality of faculty. Therefore, out of three statements belonging to quality of curriculum, one was eliminated from the analysis. Second round of factor analysis was run to split curriculum and faculty using scree plot to see whether they could be separated. This round of analysis separated faculty and curriculum along with other distinct factors which is presented in Table 1. Remaining seventeen statements are presented in Table 3. Table 1

Factor Result of Independent Variables for Quality Aspects

\begin{tabular}{|c|c|c|c|c|c|}
\hline Items & Infrastructure & Employability & Faculty & Reputation & Curriculum \\
\hline 1 & .862 & -.070 & .143 & .107 & .039 \\
\hline 2 & .797 & .147 & .004 & -.008 & .128 \\
\hline 3 & .786 & .048 & .245 & .077 & .171 \\
\hline 4 & .712 & .080 & .332 & .077 & .032 \\
\hline 5 & .654 & .388 & .005 & .212 & -.080 \\
\hline 6 & .023 & .794 & .061 & .239 & .187 \\
\hline 7 & .163 & .785 & .306 & .101 & .165 \\
\hline 8 & .132 & .771 & .281 & .135 & .097 \\
\hline 9 & .093 & .762 & .086 & .305 & .271 \\
\hline
\end{tabular}

Journal of Education and Research, March 2013, Vol. 3, No. 1 


\begin{tabular}{cccccc}
\hline Items & Infrastructure & Employability & Faculty & Reputation & Curriculum \\
\hline 10 & .133 & .181 & $\underline{.822}$ & .154 & .136 \\
11 & .168 & .131 & $\underline{.820}$ & .152 & .197 \\
12 & .284 & .271 & $\underline{.710}$ & .078 & .167 \\
12 & .024 & .240 & .150 & $\underline{.815}$ & .122 \\
14 & .230 & .245 & .103 & $\underline{.763}$ & .168 \\
15 & .153 & .272 & .406 & $\underline{.556}$ & .384 \\
16 & .091 & .292 & .229 & .157 &. .817 \\
17 & .135 & .237 & .237 & .244 & .806 \\
Number of & 5 & 4 & 3 & 3 & 2 \\
Items & & .877 & .835 & .790 & .829 \\
Alfa & .849 & 3.72 & 3.65 & 4.03 & 3.86 \\
Mean & 3.74 & 3.061 & 2.533 & 1.939 & 1.792 \\
Eigen Value & 3.213 & & & \\
\hline
\end{tabular}

Table 1 indicated that none of the items had cross loadings and the loading score were sufficient (higher than .60) except in one item (related to reputation). Consequently, the loaded items were assessed for reliability through Cronbach's alphas to assess whether all the items belonging to every single construct consistently measured the same construct. The alphas higher than .70 indicated that they were reliable. Therefore, all the independent variables were used for further analysis.

Using the same approach, items measuring the outcome (dependent) variables were evaluated through factor analysis. Initial round of factor analysis indicated that eight items intended to measure the perceived quality and perceived value were loaded into single construct supporting the facts that both of them were quality measures. The second round of factor analysis using scree plot separated these items into two obvious constructs namely four items for perceived quality and three items for perceived value (Table 2). Cronbach's alphas higher than .70 and factor loading exceeding .60 indicated that the constructs measured were reliable and valid.

Table 2

Factor Result of Dependent Variables for Quality Constructs

\begin{tabular}{ccc}
\hline Items & Perceived Quality & Perceived Value \\
\hline 1 & $\underline{.891}$ & .153 \\
2 & $\underline{.816}$ & .342 \\
3 & $\underline{.700}$ & .400 \\
4 & $\underline{.693}$ & .450 \\
5 & .177 & $\underline{.884}$ \\
6 & .340 & $\underline{.704}$ \\
7 & .476 & $\underline{.608}$ \\
No. of items & 4 & .745 \\
Alfa & .869 & 3.87 \\
Mean & 3.78 & 2.150 \\
Eigen Value & 2.803 & \\
\hline
\end{tabular}


Summated scales were calculated by averaging each respondent's scores of the loaded items belonging to each of the constructs of independent and dependent variables for further analysis. The mean scores of all the constructs were greater than three which indicated that the respondents had positive evaluation of all the quality aspects. The loaded factors and their items were presented in Table 3.

Table 3

Items Loaded in Factor Results

Dependent variables

Perceive Quality

1. B-school X offers very good quality MBA programs.

2. B-school X offers MBA of consistent quality.

3. B school X offers very reliable MBA.

4. B-School X offers MBA with excellent features.

Perceived Value

5. MBA from B-school $\mathrm{X}$ is good value for money.

6. I consider admitting into $\mathrm{B}$ school $\mathrm{X}$ for $\mathrm{MBA}$ is a good decision.

7. Considering what students pay for MBA of B-School X, they would get much more than their money's worth.

Antecedent (independent) variables

Faculty

8. B-school X has qualified faculty in its MBA program.

9. B-school X has professional faculty in its MBA program

10. B-school X has competent faculty in its MBA program Infrastructure

11. B-school X has a good building for its MBA program.

12. B-school $X$ has a well equipped library for its MBA program.

13. B-school $\mathrm{X}$ has good computer labs for its MBA program.

14. B-school X has good classrooms for its MBA program.

15. B-school X has a good open area for its MBA program.

Employability

16. B-school X creates opportunities for a highly paid job after MBA.

17. B-school X has a good placement of MBA graduates.

18. B-school X's MBA graduates have earned a good money.

19. B-school X's MBA graduates achieved higher career positions.

Curriculum

20. MBA in B-school X provides practically oriented knowledge.

21. MBA in B-school X provides practical assignments.

Reputation

22. I trust MBA of B-school X.

23. The MBA of B-school X has credibility.

24. Getting admission in MBA of B-school X will be pride for the students. Note: B-school X indicates the name of an education institute that respondents evaluated during the survey. 
Table 3 explained definition of the instrument and factors and corresponding items. For example, perceived quality indicates good, consistent and reliable features of the education program. Similarly, perceived value refers to good value or gain against the investment in education program. Quality of faculty was measured by qualification, competence and professionalism in the faculty. Quality of infrastructure was indicated by good building, library, computer lab, class rooms and open area. Employability was measured by good career opportunities and high salary after graduation. Quality of curriculum was measured by inclusion of practical exercises and assignments in the course delivery. Finally reputation was indicated by trust, credibility of the program of the institutions and pride of being associated with the education program of the particular institution. Inclusion of these items after the analysis of reliability and validity indicated that the respondents agreed upon the definition of the constructs, items and instrument. They were also supported by literature reviews.

\section{Results}

The valid items and constructs were used for further analysis through correlation and multiple regression analysis. The correlation analysis was carried out to study the interrelationship among the variables to assess the degree of convergence and divergence among the variables. Similarly, regression analyses were carried out to assess the determinants of dependent variables.

Table 4

Correlations among Constructs

\begin{tabular}{|c|c|c|c|c|c|c|}
\hline & $\begin{array}{l}\text { Perceived } \\
\text { value }\end{array}$ & Reputation & Faculty & Infrastructure & Employability & Curriculum \\
\hline $\begin{array}{l}\text { Perceived } \\
\text { quality }\end{array}$ & $.703^{* *}$ & $.684^{* *}$ & $.547^{* *}$ & $.397^{* *}$ & $.527^{* *}$ & $.600^{* *}$ \\
\hline $\begin{array}{l}\text { Perceived } \\
\text { value }\end{array}$ & & $.685^{* *}$ & $.502^{* *}$ & $.315^{* *}$ & $.552^{* *}$ & $.516^{* *}$ \\
\hline Reputation & & & $.504^{* *}$ & $.345^{* *}$ & $.570^{* *}$ & $.575^{* *}$ \\
\hline Faculty & & & & $.438^{* *}$ & $.479^{* *}$ & $.523^{* *}$ \\
\hline Infrastructure & & & & & $.342^{* *}$ & $.301^{* *}$ \\
\hline Employability & & & & & & $.549^{* *}$ \\
\hline $\begin{array}{l}\quad * * * \text { Con } \\
\text { Table } 4 \\
\text { perceived qualit } \\
\text { In other words, } \\
\text { are concerned } \mathrm{w} \\
\text { education. Simi } \\
\text { and perceived v } \\
\text { significant role } \\
\text { correlations did } \\
\text { were divergent }\end{array}$ & $\begin{array}{l}\text { relation is } \\
\text { indicated } \mathrm{t} \\
\mathrm{y}(\mathrm{r}=.702 \\
\text { both const } \\
\text { ith their ir } \\
\text { larly, repu } \\
\text { alue excee } \\
\text { in increasi } \\
\text { not excee } \\
\text { and they } \mathrm{m}\end{array}$ & $\begin{array}{l}\text { ignificant a } \\
\text { at perceive } \\
\mathrm{p}=.000) \mathrm{v} \\
\text { ucts measul } \\
\text { vestment an } \\
\text { tion had si } \\
\text { ling .60. Th } \\
\mathrm{g} \text { perceptio } \\
.60(\mathrm{p}=.0\end{array}$ & $\begin{array}{l}\text { he } 0.001 \\
\text { value wa } \\
\text { hich indi } \\
\text { d percei } \\
\text { costs wi } \\
\text { ificant c } \\
\text { result al } \\
\text { of quali }\end{array}$ & $\begin{array}{l}\text { level } \\
\text { S significant } \\
\text { ated that bo } \\
\text { ed quality. I } \\
\text { h regard to } \\
\text { rrelation wi } \\
\text { o indicated } \\
\text { y among th } \\
\text { ndicated tha }\end{array}$ & $\begin{array}{l}\text { correlated } \\
\text { were conve } \\
\text { ndicates tha } \\
\text { quality of } \\
\text { perceived } \\
\text { at reputatio } \\
\text { ublic. The } \\
\text { ndependent }\end{array}$ & $\begin{array}{l}\text { th } \\
\text { the public } \\
\text { gher } \\
\text { tality } \\
\text { played a } \\
\text { st of the } \\
\text { ariables }\end{array}$ \\
\hline
\end{tabular}


Table 5

Regressions Model of Quality Attributes on Quality Constructs

\begin{tabular}{ccccccc}
\hline $\begin{array}{c}\text { Dependent } \\
\text { variables }\end{array}$ & \multicolumn{3}{c}{ Perceived quality } & \multicolumn{4}{c}{ Perceived value } \\
\hline $\begin{array}{c}\text { Independent } \\
\text { variables }\end{array}$ & $\begin{array}{c}\text { Standardized } \\
\text { Coefficients } \\
\text { Beta }\end{array}$ & $\mathrm{t}$ & Sig. & $\begin{array}{c}\text { Standardized } \\
\text { Coefficients } \\
\text { Beta }\end{array}$ & $\mathrm{t}$ & Sig. \\
\hline Reputation & .417 & 6.710 & .000 & .473 & 7.272 & .000 \\
Faculty & .148 & 2.540 & .012 & .137 & 2.239 & .026 \\
Infrastructure & .098 & 1.922 & .056 & .008 & .149 & .882 \\
Employability & .055 & .914 & .362 & .161 & 2.548 & .012 \\
Curriculum & .223 & 3.728 & .000 & .081 & 1.295 & .197 \\
F & & 56.837 & & & 48.042 & \\
$\mathrm{P}$ & & .000 & & & .000 & .529 \\
$\mathrm{R}^{2}$ & .570 & & & & \\
\hline
\end{tabular}

Table 5 show that both of the regression models were significant with $\mathrm{R}^{2}$ of more than .52 at $\mathrm{p}$ value of 0.001 level. The regression analysis indicated that perceived quality was determined by reputation of the program, curriculum and faculty $(\mathrm{t}>2$ and $\mathrm{p}<0.01)$. On the contrary, perceived value was determined by reputation, employability and faculty $(t>2$ and $p<0.01)$. Infrastructure did not contribute in enhancing both types of quality perspectives. Predominance of reputation in contributing to quality perceptions and meager contributions of other factors increased the relevance of exploring whether the attributes under the study contributed in the reputation of the program. Therefore another regression analysis was undertaken to identify the determinants of reputation.

Table 6

Determinants of Reputation

\begin{tabular}{cccc}
\hline Independent variables & $\begin{array}{c}\text { Standardized } \\
\text { Coefficients Beta }\end{array}$ & $\mathrm{t}$ & Sig. \\
\hline Faculty & .155 & 2.449 & .015 \\
Infrastructure & .093 & 1.674 & .096 \\
Employability & .345 & 5.582 & .000 \\
Curriculum & .277 & 4.399 & .000 \\
F & & 49.573 & \\
P & & .000 & \\
$\mathrm{R}^{2}$ & & .480 & \\
\hline
\end{tabular}

Table 6 indicated that employability, curriculum and faculty respectively contributed to reputation. The model was fit and $\mathrm{R}^{2}$ was also significant. Therefore, reputation as a symbolic representation of education program was enhanced by the perception of employability followed by curriculum and faculty. Reputation was not contributed by physical attributes such as infrastructure. 


\section{Discussion}

This study used the theory of consumer perception to explore the determinants of perceived quality in order to address its inadequate and ambiguous explanation by total quality management. This study explored how public in general who are exposed to stimuli of physical attributes such as physical facilities and symbolic attributes such as employability, faculty, curriculum, reputation understand and draw meaning of perceived quality and perceived value of higher education program. The study found out that the stakeholders perceive different physical and symbolic attributes of higher education program. The scale and instrument used for measuring perceived quality and perceived value and corresponding antecedents are reliable and valid. For example, perceived quality scale included attributes such as good, consistent and reliable features of the education program. Similarly, perceived value is found to be measuring perception of good value or gain against the investment in education program. Faculty is perceived with three symbolic words such as qualified, competent and professionalism. Quality of infrastructure refers to good building, library, computer lab, class rooms and open area. Employability is the perception of having career opportunities and good salary after graduation. Curriculum is indicated by inclusion of practical exercises and assignments in the courses. Finally, reputation is indicated by trust and credibility of education program and pride of being students of the program. These definitions are consistent with several other researches (Pappu, Quester, \& Cooksey, 2005; Shrestha, 2011).

Perceived value is significantly correlated with perceived quality which indicates that both constructs measure perceived quality. Therefore, public is concerned not only with attributes but they also compare them with the investment and costs involved in participating in the education programs.

Perceived quality is determined by reputation of the program, curriculum and faculty. On the contrary, perceived value is determined by reputation, employability and faculty. Infrastructure did not contribute in enhancing both types of quality perspectives. All the antecedent variables are symbolic in nature because they are not tangible attributes. Furthermore, reputation as predominant factor contributing to quality perceptions also supports that symbolic attributes are more important than tangible and functional attributes for stakeholders. Perceived quality is determined by input and process of education program such as curriculum and faculty. Perceived value is influenced by outcome variables such as employability as it measures quality against costs involved in education program.

Further analysis on reputation indicated that symbolic representation of education program is enhanced by the perception of employability followed by curriculum and faculty. Reputation is still not contributed by physical attributes such as infrastructure. These findings are consistent with earlier literature on quality of higher education in which parents and employers were concerned with reputation and employability (Chua, 2004).

Overall, this study indicated that public focus on the process and output rather than input of the education system when they consider quality of any education program. They consider reputation as credibility and trust of the program which is 
created by practical curriculum delivered by competent faculty and track record of past students getting good employment. They also compare the attributes and benefits against the price or costs of the program. These findings are consistent with many research findings especially designed for students' evaluation of the education program (Gatfield, Braker, \& Graham, 1999; Bindsardi \& Ekwulugo, 2003; Ho \& Hung, 2008).

\section{Managerial and Research Implications}

This study has policy and managerial implications regarding how to determine quality of any education programs. The focus on improving quality impression among the target population should be on improvement of reputation of the program by using practical curriculum delivered by qualified and competent faculty. Similarly, the education institutions should promote and highlight graduate employability by indicating the career success and development of their graduates. The education institutions should have good building with well equipped library, computer lab, class rooms and open areas but they were not considered quality indicators by the public. Therefore, they should not be overemphasized in their advertisement and other promotion programs. The fees and other charges should match with the reputation that the education programs have earned in terms of credibility and trust in offering practical curriculum delivered by competent faculty and employment prospects. The ranking of the education program and institutions should emphasize three aspects: whether the curriculum is practical enough, whether the competent faculties deliver the course practically and whether the students are well accepted by employers and get good career opportunities. This research should be replicated in other education programs to enhance the generalizability of the results. This study replicated the variables and scales used in previous researches. As a result, other variables besides those included in the study might also be contributing factors on perceived quality. Future study should include those other variables.

\section{Conclusion}

This study identified antecedents of perceived quality of education program from the perspective of the public. The public in general is not concerned with organizational process and corresponding monitoring process. Therefore, TQM approach has less meaning to public perception. Public is concerned primarily with credibility and trust of the program. They consider education has quality when they assume the education programs develop graduate employability and practical skills among the students. Therefore, they are concerned with process and output of any education programs. Another important finding is that public is concerned with the process of delivering education with practical curriculum and practical delivery of the faculty. They were not at all interested in input such as infrastructure. When they measure quality as attributes alone, they consider curriculum and faculty important factors but when they compare the attributes with the price, they would give attention to employability and faculty. Although competent faculty has less contribution in enhancing perceived quality and perceived value, they are important contributing factors to make curriculum practical and deliver practical skills to enhance students' employability. They finally increase 
reputation as symbolic attributes of education program. Therefore, reputation can be considered outcome of the education programs.

\section{References}

Baldwin, G., \& James, R. (2000). The market in Australian higher education and the concept of student as informed consumer. Journal of Higher Education Policy and Management, 22(2), 139-148.

Bindsardi, A., \& Ekwulugo, F. (2003). International marketing of British education: Research on the students' perception and the UK market penetration. Marketing Intelligence and Planning, 21(5), 318-327.

Bourkie, A. (2002). A model of the determinants of international trade in higher education. The Service Industries Journal, 20(1), 110-138.

Chua, C. (2004). Perception of quality in higher education. Proceeding of the Australian University Forum. Retrieved from https://citeseerx.ist.psu.edu/viewdoc/ download?doi\%3D10.1.1.125.3578

Dill, D. D. (2003). Allowing the market to rule: The case of the Unites States. Higher Education Quarterly, 57, 136-157.

Dill, D. D., \& Soo, M. (2005). Academic quality, league tables, and public policy: A cross-national analysis of university ranking system. Higher Education, 49, 495533.

Gatfield, T., Braker, B., \& Graham, P. (1999). Measuring communication impact of university advertising materials. Corporate Communications: An International Journal, 4(2), 73-79.

Gray, B., Fam, K., \& Llanes, V. (2003). Branding universities in Asian markets. Journal of Product \& Brand Management, 12(2), 108-120

Ho, H., \& Hung, C. (2008). An integrated analysis employing analytic hierarchy process, cluster analysis and correspondence analysis. International Journal of Educational Management, 22(4), 328-340.

Ivy, J. (2001). Higher education institution image: A correspondence analysis approach. The International Journal of Educational Management, 15(6/7), 276-282.

Kotler, P., \& Keller, K. L. (2009). Marketing management (13th ed.). NJ: Prentice Hall. Netemeyer, R. D., Krishnan, B., Pullig, C., Wang, G., Yagci, M., Dean, ... Wirth, F. (2004). Developing and validating measures of facets of customer- based brand equity. Journal of Business Research, 57, 209-224.

Nicholls, J., Harris, J., Morgan, E., Clarke, K., \& Sims, D. (1995). Marketing higher education: The MBA experience. The International Journal of Educational Management, 9(2), 31-38.

Owlia, M. S., \& Aspinwall, E. M. (1996). A framework for the dimensions of quality in higher education. Quality Assurance in Education, 4(2), 12-20.

Pappu, R., Quester, G. P., \& Cooksey, W. R. (2005). Consumer -based brand equity: Improving the measurement empirical evidence. The Journal of Product and Brand Management, 14(2/3), 143-154.

Sahney, S., Banwet, D. K., \& Karunes, S. (2004). Conceptualizing total quality management in higher education. The TQM Magazine, 16(20), 145-159. 
Schiffman, L. G., Kanuk, L. L., \& Kumar R. S. (2010). Consumer behavior (10th ed.). New Delhi: Prentice-Hall.

Shrestha, B. K. (2011). Brand equity of higher education in Nepal (Unpublished doctoral thesis). Kathmandu University, School of Education, Nepal.

Soutar, G. N., \& Turner, J. P. (2002). Students' preferences for university: A conjoint analysis. The International Journal of Educational Management, 16(1), 40-45.

Srikanthan, G., \& Daltrymple, J. (2003). Developing alternative perspectives for quality in higher education. International Journal of Educational Management, 17(3), 126 $-136$.

Srikantanyoo, N., \& Gnoth, J. (2002). Country image and international tertiary education. Journal of Brand Management, 10(2), 139-146.

Vaira, M. (2004). Globalisation and higher education organizational change: A framework for analysis. Higher Education, 48(4), 483-510.

Zeithamal, V. A. (1988, July). Consumer perceptions of price, quality, and value: A means-end model and synthesis of evidence. Journal of Marketing, 52, 2-22. 